\title{
Limitation Legal Certainty of Long-Term Flat unit Ownership Related to Flat Building Ownership
}

\author{
Sukiman Sugita*, Abdul Gani Abdullah, Gunawan Djajaputra \\ Faculty of Law, Tarumanagara, Jakarta, Indonesia
}

Received: 24/05/2020

Accepted: 29/07/2020

Published: 20/09/2020

\begin{abstract}
Humans in carrying out their lives must meet certain requirements of life which consists of several levels based on their interests, including the most basic primary needs met first by Humans, Secondary Needs that arise and support primary needs and tertiary needs that can be fullfiled after primary and secondary needs. Basic needs in this case will describing human needs for shelter or a place to stay as their needs to living. The need for flats is inevitable to meet the need for shelter for the people of Indonesia, especially related to the dense population in urban areas. However, the existing regulations cannot provide legal certainty due to material and formal requirements that need to be provided in providing legal certainty have not been regulated so that it can be implemented optimally. This research was conducted using a legal approach that prioritizes several legal theories to analyze and test the laws and regulations related to the limitations of ownership of flats that are timed to be associated with building ownership so that ownership is expected to provide recommendations and suggestions for developing policies that provide significant benefits in reforming the legal provisions and the usefulness, justice and legal certainty in Indonesia.
\end{abstract}

Keywords: Flat building, Flat unit, Legal certainty, Ownership

\section{Introduction}

Land is an object in meeting the needs of human which has a very important meaning. Land is a gift from God almighty as a natural resource which is controlled by the state to meet the needs of human life for shelter, farming, trade, industry, education, to the construction of facilities and other infrastructure and become a final resting place for human (1). The problems that occur related to land become evidence of the need for state interference and the law that governs and provides legal certainty. Roscou Pound provides a legal basis for the systematic requirements of the law as follows (2). In a civilized society everyone can hope that others will not attack them. In a civilized society everyone can expect that he can own for the purposeful use of what they find and use for his own benefit, what they create, with their own work and what they earn, in the social and economic order that that time held power. In a civilized society everyone can expect that the people with whom they deal with public relations in society will act in good faith. It can be expected that they will fulfill the promises they have been able to fulfill or the hopes they have created because of their actions.

\section{Methodology (Literature Review)}

The state as a community entity has an outline of its purpose and function, the state aims to ensure equality for its people, the State functions to resolve disputes, conflicts and meeting the needs of the Common life. The state is an instrument of shared interest in achieving happiness (3). To achieve the common goal, human being needs to have a state. Because, that country will has an organization of power rather than Human. Society is a tool that will be used to achieve that

Corresponding author: Sukiman Sugita, Faculty of Law, Tarumanagara, Jakarta, Indonesia. E-mail: alexander.ssugita@yahoo.com goal. As a country with population estimate of 265 million people, it is reasonable if housing and settlements are one of the basic needs that are influential in shaping the personality of the Indonesian people. Housing and Settlements can not only be seen as a means of necessity of Life, but more than that it is a process of settling Humans in creating living arrangements for the community and himself in expressing identity (4). There are two roles of government in housing construction anywhere in the World, namely the government as the housing developer itself or at least facilitates housing development and as a controller for housing development (5). High population growth is in line with the level of demand for housing that is getting higher, but the high demand is not directly proportional to the availability of land for housing, especially in densely populated urban areas. This has caused many housing developers to start innovating by making vertical-shaped dwellings. Vertical dwellings are commonly known as Apartment and Flats (6).

In granting a clear legal status for the implementation of flats, the government has formed a legal instrument that regulates the implementation of flats. This is stated in the Flats Act. The formation of legal instruments becomes important to provide legal protection for people who wish to have residential housing in the form of flats. Law Number 20 Year 2011 concerning Flats (UURUSUN) creates a firm legal basis relating to the implementation of flats based on the principles of welfare, justice and equity, benefits. The policy direction for the construction of flats in Indonesia as stated in UURUSUN includes three main elements, namely: (1) Spatial Planning and urban development, using land optimally and realizing settlement in population density. (2) The concept of legal development, by creating new material rights, that is, flat flats that can be owned individually by joint ownership of objects, parts and land and creating a new legal entity that is the association of residents who with their articles of association and household budgets can act out and in the name 
of the apartment unit owner, has the authority to realize order and peace in the apartment life. (3) Concept of Economic Development and business activities with the possibility of construction credit and mortgages or fiduciary loading of land along with buildings that will still be built with the existence of dynamic settlement problem in the community, especially in crowded cities, there are legal consequences, especially regarding ownership and ownership rights (7). As stated in agraria basic law number 5 of 1960 article 20, this article explains that the right of ownership is the strongest right and fulfillment that can be owned by people on the land, the granting of these characteristics means that the right is absolute and cannot be contested. Law No. 20 of 2011 concerning Flats regulates property rights in article 4 paragraph 1 . Property rights over housing units a separate structure which is separated from the Joint right in the Joint portion, Common objects and shared land. To ensure legal certainty and ownership and investment of the Republic of Indonesia government guarantees these rights in law number 25 of 2007 concerning investment and to provide certainty and guarantee of comfort, equity of justice and consumer safety and legal certainty for the public over ownership of apartment units. The government regulates it in law No. 8 of 1999 concerning consumer protection. With the existence of these legal products, it is expected to provide legal certainty, usefulness and protection for the community towards ownership of flats in Indonesia.

1) Government's role in the current implementation of Flats: The government is all state equipment or state institutions that function as a means to achieve the goals of the state, while what the government does is in the context of carrying out the tasks of the state so that the government is often referred to as state representation. Basically the role of the government in the procurement of housing can be divided into two:

(a) Policy makers Rational housing procurement strategies and programs (8). Limitation of ownership of flats that are timed in association with ownership of this building, the government should formulate policies both legally and practically so as to provide benefits and justice for housing development, especially flats in force in Indonesia. The government should be able to meet the needs and development dynamics of development by immediately making a legal effort to reform and harmonize the provisions of the basic agraria laws, the Investment Act and the Law on Flats, by following the acceleration of development of residential houses, especially flats.

(b) Implementation of affordable housing procurement in relation to flats for low-income communities. The government acts as the provider or as an enabler, that is, when the government acts as the producer of the house or provider, the government is responsible and the decision maker making it easier for the public and investors to obtain certainty. The task of the government is to create a conducive climate and provide a variety of community assistance to be able to participate in the procurement of housing and the role of the government must provide facilities for apartment developers so as to create a good investment climate and provide legal certainty over the ownership of flats. With government intervention from the beginning of the licensing, ownership, development and control processes and mechanisms in accordance with statutory provisions and legal certainty, so that legal problems do not occur in the future. Flats Development aims to meet the needs of the community, especially in urban areas that are livable and affordable for middle to lower income people in urban areas with dense population. The construction of these flats will have an impact on increasing the efficiency of land use, space and capacity of the city, improving the quality of life of middle to lower income people and preventing the growth of urban slums, increasing the efficiency of infrastructure, urban facilities and utilities, increasing community productivity and urban competitiveness, increasing community productivity and city competitiveness, increasing meeting housing needs for the middle and lower classes and increasing employment and economic growth (9), (10).

Flats in urban areas are based on the concept of sustainable development, which places people at the center of development. In its implementation, use the principles of good governance and good corporate governance. The basic principle of the construction of flats refers to the principles of the construction of flats; the construction of flats is a government responsibility that can be carried out by everyone by getting help from the government and also by non-profit organizations and business entities. Payment of commercial flats can be carried out by anyone, where the offender provides public flats with at least $20 \%$ of the total floor area of the commercial flats built. Obligations to pay for these public flats can be made outside the location of commercial flats while still within the district / the same city as the commercial flat related.

Construction of flats is regulated by government regulation No. 4 of 1988 concerning flats, the law on flats provides regulations on types of flats that were not previously regulated, namely public flats, special flats, state flats and commercial flats. This is not yet regulated in the regulations of apartment houses, so the regulations on apartment houses need to be adjusted. This is important considering the characteristics of each apartment and the restrictions on their use and use are regulated differently. The role of the government in the construction of flats is regulated in law number 20 of 2011 concerning flats which includes the role and policy of how to implement the construction and regulation of ownership of flats, this has been regulated in the provisions of government regulation No. 24 of 1997 concerning land registration and Law number 38 of 2008 concerning Buildings. As the author described above, the role of the government must be to provide legal certainty for the community and legal certainty of good investment so that with clear certainty, community trust in the certainty of ownership of flats and other matters guaranteeing ownership rights. This is stated in law number 25 of 2007 concerning investment. In article 22 of Law Number 25 Year 2007 regarding the period of ownership of land as a basis for investment provisions that should be maintained in order to provide certainty for the period of extension of ownership that can provide a sense of security and certainty over building ownership, with changes through judicial review, making the public and investors have reduced trust in the government. How the task of government is should be able to provide a sense of comfort, fairness and expediency for the benefit of the wider community. Thus it is not easy for a legal product to change. The role of the government must be to provide certainty and good and strong legality so that the community can feel protected, even though there is now law number 8 of 1999 regarding consumer protection that is still lacking by the public, because too many legal products cannot provide protection in a manner certainly for the community in general, especially the principle of certainty of ownership of flats, this must be immediately addressed and repaired because the need for flats increases in urban areas in Indonesia.

(2) Legal certainty of limits on ownership of flats with time duration related to building ownership. Based on the terms of ownership of flats with a time frame associated with 
ownership of buildings in Indonesia, at least based on five laws and regulations, namely: The 1945 Constitution, in particular Article 33 Paragraph 3, Basic Agrarian Law Number 5 of 1960, Investment Act No. 25 of 2007, Flats Act No. 20 of 2011. Regulation of the Minister of Public Works and Public Housing No. 23 of 2018 regarding associate of flats owner. According to Sudikno Mertokusumo, legal certainty is a guarantee that the law can be carried out properly. Certainly legal certainty has become an inseparable part. This is prioritized for written legal norms, because certainty itself is essentially the main goal of the law, this legal certainty is the regularity of the people and is closely related to certainty itself because the essence of order will cause a person to live in harmony certainty in carrying out the activities required in carrying out the activities of community life itself (11). Philosophical and Juridical Basis for the Conception of the National Land Law, Justice, Humanity and Sovereignty is a reflection of the spirit of article 33 paragraph 3 of the 1945 Constitution which is the basis of the UUPA itself gives and places a right in its place based on a principle that all people have the same position in before the law, where the state is involved in the regulation of ownership provisions. The concept and principle of Horizontal separation in land, Horizontal Separation states that buildings and plants are not part of the land, consequently the land boundary does not automatically include the ownership of the buildings and plants on it. The application of the principle of horizontal separation is a consequence of the inclusion of elements of customary law in national land law, this makes a rule of ownership ambiguous, the principle of horizontal separation in land law is a legal product in Indonesia that does not reflect the legal function to provide legal certainty to achieve justice and efficiency. The role of the government must be explicitly able to regulate the rights of ownership, especially for timebound flats associated with building ownership. That the issuance of government regulation number 40 of 1996 and UUPM which specifically provides a tool in the form of extension of secondary rights from individual rights or individual rights is a good breakthrough and should be appreciated for the obligations or facilities for extension of secondary rights. This is regulated in article 22 of the Capital Market Law regarding the period of acquisition of rights at the same time the Capital Market Law provides 80 years of building use rights by being granted and extended for 50 years and renewable for 30 years. This is very good for the certainty and legality of ownership of flats that can provide certainty over the unit period obtained by the owner of the flats, but this cannot be done because of other views from various parties and conduct a judicial review of the law. This makes uncertainty over laws and regulations that can change which leading to uncertain regulations. Gustav Radbruch stated 4 basic things related to the meaning of legal certainty that can be associated with the Limitation of ownership of flats that have a period of time associated with building ownership. First, that the law is positive, meaning that the positive law is legislation which means that the positive law discussed in this journal is the agrarian main law (UUPA), the investment law, and the law of the flats that for the three laws these laws must work in harmony to provide a useful legal certainty. Secondly, that the law is based on facts which mean that it is based on reality in people's lives, the fact that there have been cases where the case was a reminder of the formation of the law. Especially regarding matters related to ownership due to the absence of legal certainty that can be a reference to legal products. Third, that the facts must be formulated clearly in purpose to avoid errors in meaning. Besides being easy to implement; the fact that it is important to formulate a harmonious rule of law in order to create legal certainty and in order to provide benefits. With clear regulations, of course, development activities will be more easily implemented and applied to reduce the risk of losses experienced by the owners of flats and the wider community and developers. Fourth, positive law should not be easily changed, in the opinion of the author as outlined on the previous page, it is fitting that the provisions of article 22 of the investment law related to the extension of secondary rights remain and are not invalidated by the constitutional court, because basically they do not violate or contradict a The law (higher statutory regulations) in this case the 1945 Constitution, which is strengthened by these rules is the same item and does not reduce the essence of the principle of the length of time stipulated in the LoGA and its implementing regulations (3). The ideal arrangement related to ownership limits for a longterm apartment is linked to building ownership. According to the authors, the certainty of the limit of ownership of flats which is connected for a long time with building ownership does not provide certainty due to various errors, complexities and unclear provisions related to formal procedures in the maintenance of ownership rights, for this reason it is necessary to reform and harmonize the provisions of the statutory regulations. Regulations related to the limitation of ownership of a long term apartment connected to the ownership of the building must be carried out both in the juridical order and the practical implementation. The basis for granting land titles for the construction of flats to the actors of flats or developer is closely related to the legal provisions relating to land titles related to investment activities. In the investment law is widely open to investors both domestic and foreign investment, it is necessary to ensure licensing and acquisition of land rights such as how much land can be obtained and the term of the land provided by the legislation to the perpetrators of home construction stacking, available land area for investment including HGB, HGU and usage rights. With the provisions of the apartment laws and investment laws, it should be able to provide a certain period of time to ensure how much time can be obtained for investments and owners of flats, because the provisions of ownership rights are clearly stipulated in article 20 of the Act Law No. 5/1960 and Law number 20 of 2011 concerning flats. And guaranteed in the provisions of law No. 25 of 2007 concerning investment, which regulates clearly and unequivocally regarding the period of ownership both for apartment units attached to land rights. In this provision clearly stipulates the time period for the acquisition of land titles as stipulated in article 22 of law number 25 of 2011 . But this provision is canceled by the constitutional court, this makes it difficult and there is no legal certainty, the law must have effectiveness the law is a process that aims at the law being effective; HGB can be granted in the amount of 80 years and can be granted and extended in advance at the same time for 50 years and can be renewed for 30 years. With the existence of these regulations there is clearly certainty over the ownership of land and buildings. This must be immediately returned and harmonized between one legal product and another legal product. So that it becomes more efficient from the existence of ease and legal certainty for the community, especially regarding ownership of flats. In the provisions of article 4 letter (b) of the investment law number 25 of 2007 explaining to guarantee legal certainty, business certainty, and business security for investment since the licensing process until the end of capital offering activities in accordance with statutory provisions. Clearly, there are provisions and limitations in the investment law number 25 of 2007 providing protection against the capital offer. According 
to the author, Article 22 of the investment law No. 25/2007 was re-enacted, providing legal certainty and time efficiency in the extension of ownership rights and certainty of ownership of buildings, especially in flats in Indonesia. With these provisions can provide certainty and comfort for both developers and investors to ensure the period of ownership of rights and buildings (12), (13).

\section{Conclusion}

The need for seriousness from the government to immediately fix the existing legal products so as to facilitate understanding for the public on a legal product that regulates the interests of the community so that the legal product can provide legal certainty, effectiveness and provide a sense of security and comfort for the property business sector and the owner of the apartment units.

Thus a legal product does not overlap with the many derivatives of a law, as is the case today with ownership of land titles and apartment buildings. The current legal products are the Agrarian Law No. 5 of 1960, the Law on Flats, Land Registration Regulation No. 24 of 1997 and the Investment Law and Law No. 8 of 1999 concerning Consumer protection. Unable to provide a sense of security, comfort and legal certainty, this can provide a bad perception for the development of flats in Indonesia. With the always changing conditions for implementing regulations that must be followed in the licensing process and other matters relating to ownership of flats. The study expects the government to immediately accommodate the needs and development of the business world and the dynamics of society that continues to move on the process of advancing times, especially reforming the basic agrarian law product no. 5 of 1960 which has been sufficiently long to be adapted to current conditions, so that it can be more certain in the future provides certainty over the ownership of special flats in Indonesia

\section{Ethical issue}

Authors are aware of, and comply with, best practice in publication ethics specifically with regard to authorship (avoidance of guest authorship), dual submission, manipulation of figures, competing interests and compliance with policies on research ethics. Authors adhere to publication requirements that submitted work is original and has not been published elsewhere in any language.

\section{Competing interests}

The authors declare that there is no conflict of interest that would prejudice the impartiality of this scientific work.

\section{Authors' contribution}

All authors of this study have a complete contribution for data collection, data analyses and manuscript writing.

\section{References}

1. Elza S. 2002. Menuntaskan Kasus Tanah Melalui Pengadilan Khusus Pertanahan. Kepustakaan Jakarta. Jakarta;2. Online: http://repository.uib.ac.id/779/1/Menuntaskan\%20Sengketa\%20T anah\%20\%28Full\%29.pdf

2. Soetikno. Filsafat Hukum. Pradnya Parasmita. Jakarta. 1997;7(2):80.

3. Ahmad S. Hukum Tata Negara \& Hukum Administrasi Negara dalam perspektif fikih siyasah. Sinar Grafika. 2014;59.

4. Arie SH. Condominium dan Permasalahannya. Badan Penerbit Fakultas Hukum Universitas. Depok. 2007.

5. Tjuk K. Perumahan dan Pemukiman di Indonesia. Penerbit ITB. Bandung. 2005.
6. Bellini OE. Adaptive Exoskeleton Systems: Remodelage for Social Housing on Piazzale Visconti (BG). In: Della Torre S., Cattaneo S., Lenzi C., Zanelli A. (eds) Regeneration of the Built Environment from a Circular Economy Perspective. Research for Development. Springer, Cham. 2020.

7. Maxim B \& Tshenolo M . Recognising the family house: a problem of urban custom in South Africa, South African Journal on Human Rights. 2019;35(2):147-168. DOI: 10.1080/02587203.2019.1632737.

8. Indonesian Law Number 5. Agraria Law. 1960.

9. Urip S. Pendaftaran dan Peralihan Ha katas Tanah. Kencana Prenadamedia Group, Solo. Pp.7a.

10. Samiee KS. Context comfort feature improvement regarding urban blocks designing based on maximal utilization of passive solar energy (Case study: Latman Kan residential site), Journal of Art and Architecture Studies. 2015;4(2):35-44.

11. Sudikno M. Penemuan Hukum. Liberty. Yogyakarta. 2009.

12. Soerjono S. Faktor Faktor yang mempengaruhi Penegakan Hukum. Penerbit PT.Raja Grafindo Persada. Jakarta. 2007.

13. Indonesian Law Number 25. Concerning Investment. Jakarta. 2007. 